Case report

\title{
Löfgren's Syndrome with Splenic Involvement: A Case Report
}

\author{
Soheil Ebrahimpour ${ }^{1}$, Mahmoud Sadeghi-Haddad-Zavareh"1, Zeinab Mohseni Afshar ${ }^{2}$ \\ Mehran Shokri ${ }^{1}$, Arefeh Babazadeh ${ }^{1}$ \\ ${ }^{1}$ Infectious Diseases and Tropical Medicine Research Center, Health Research Institute, \\ Babol University of Medical Sciences, Babol, Iran \\ ${ }^{2}$ Clinical Research Development Center, Imam Reza Hospital, Kermanshah University \\ of Medical Sciences, Kermanshah, Iran
}

\section{SUMMARY}

Löfgren's syndrome is an acute form of sarcoidosis characterized by fever, erythema nodosum (EN), bilateral hilar lymphadenopathy (BHL), and polyarthritis. This syndrome is a self-limiting disease. A 45year-old woman was admitted to our hospital complaining of fever, visual blurring, and arthralgia. A chest radiograph showed bilateral hilar mass lesions. High-resolution computed tomography (HRCT) scans of the chest revealed multiple nodules at different segments of the lung, bilateral hilar and paraesophageal lymphadenopathy. Also, abdominal and pelvic CT scan showed mild splenomegaly, with multiple hypodense nodules in the spleen and an accessory spleen. She was diagnosed with Lofgren's syndrome.

Key words: Löfgren's syndrome, sarcoidosis, polyarthritis,erythema nodosum

Corresponding author:

Arefeh Babazadeh

Email: drbabazadeh.a@yahoo.com 


\section{INTRODUCTION}

Sarcoidosis is a granulomatous disorder of unidentified cause that affects several organs in the body (1).This systemic disease is characterized by noncaseating granulomatous inflammation with some giant cells. Sarcoidosis may affect the lymph nodes, eyes, heart, spleen, and skin (2). This disorder produces enlarged lymph nodes of pulmonary hila. About $90 \%$ of patients with sarcoidosis have lung engagement (3). This multi-system disease involving the musculoskeletal system is infrequent. Furthermore, it can involve the synovitis of large joints of lower extremities and proximal muscles (4). Sarcoidosis usually occurs in young and middle-aged people, mainly affecting women (5). Timely diagnosis of this disorder still poses difficulties because of varying presentations. For that reason, clinicians must be aware of the varied range of this disease manifestations, and avoid a delay in exact diagnosis and treatment. Löfgren's syndrome is an acute form of sarcoidosis and approximately $30 \%$ of sarcoidosis cases present with Löfgren's syndrome (6). It is characterized by several signs and symptoms such as fever, rash, erythema nodosum (EN), polyarthritis, and bilateral hilar lymphadenopathy (BHL) (7). Its prognosis is excellent and almost all of these cases respond to corticosteroid therapy. Herein, we report a middle-aged woman with Löfgren's syndrome with splenic involvement.

\section{CASE REPORT}

A 45-year-old woman presented to the Infectious Disease Clinic with three weeks of intermittent fever, visual blurring, and arthralgia. She had no other complaints but an acute episode of rectorrhagia. On examination, she had frank bilateral ankle arthritis and EN was noted bilaterally over the lower limbs. Ophthalmic examination showed blood-vessel branching suggestive of scleritis. The results of laboratory analysis were as follows: serum glutamic-oxaloacetic transaminase (SGOT), $30 \mathrm{U} / \mathrm{L}$; serum glutamic pyruvic transaminase (SGPT), 23 $\mathrm{U} / \mathrm{L}$; alkaline phosphatase (ALP ), $154 \mathrm{U} / \mathrm{L}$; lactate dehydrogenase (LDH), $340 \mathrm{U} / \mathrm{L}$; creatine kinase (CK), $1213 \mathrm{U} / \mathrm{L}$; C-reactive protein (CRP), 2+; erythrocyte sedimentation rate (ESR), $58 \mathrm{~mm} / \mathrm{h}$; serum angiotensin-converting enzyme (ACE), $121 \mathrm{U} / \mathrm{L}$; serum calcium, $7.3 \mathrm{mg} / \mathrm{dL}$. The serum agglutination test (SAT) and 2-mercaptoethanol (2 ME) agglutination

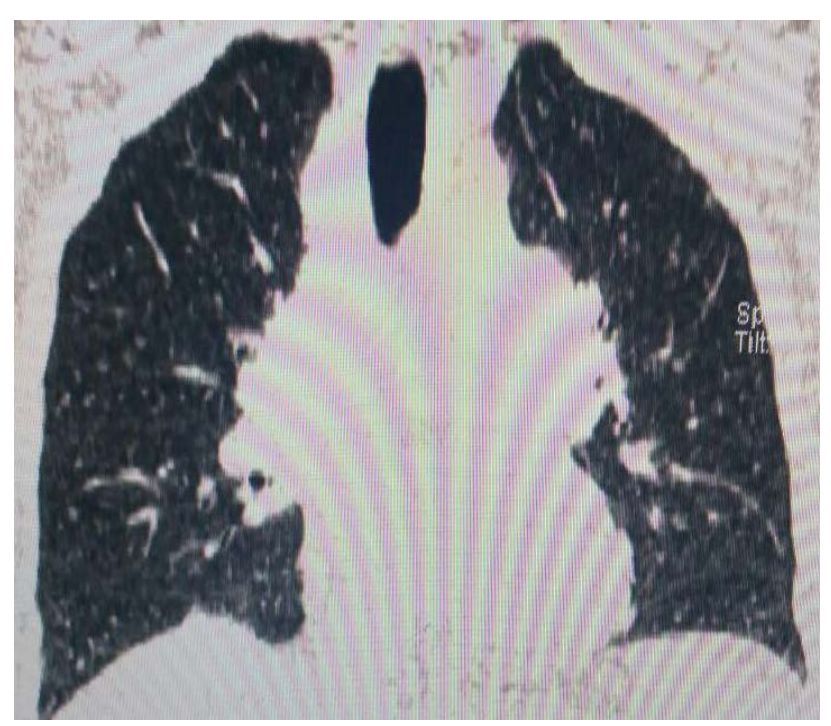

Figure 1. A chest $x$-ray revealed bilateral hilar mass lesions

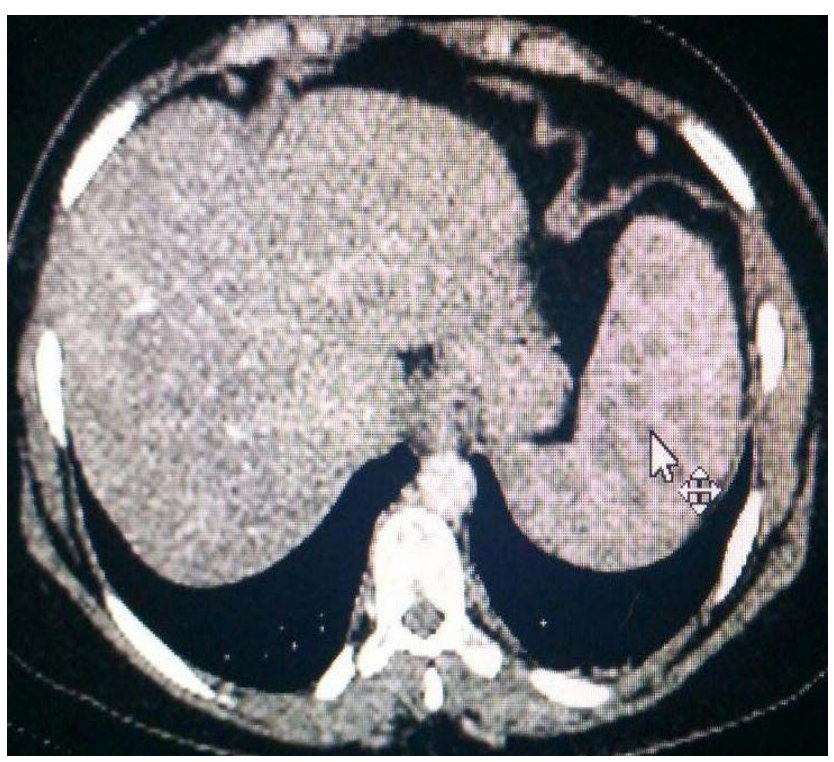

Figure 2. Axial CT scan revealed mild splenomegaly, with multiple hypodense nodules in the spleen and an accessory spleen

were negative. Stool examination results and complete blood count $(\mathrm{CBC})$ were normal. Her chest x-ray showed bilateral hilar mass lesions (Figure 1). Highresolution computed tomography (HRCT) scans of the chest revealed multiple nodules at different segments of the lung, bilateral hilar and paraesophageal lymphadenopathy. Abdominal and pelvic $C T$ scan showed mild splenomegaly, with multi- 


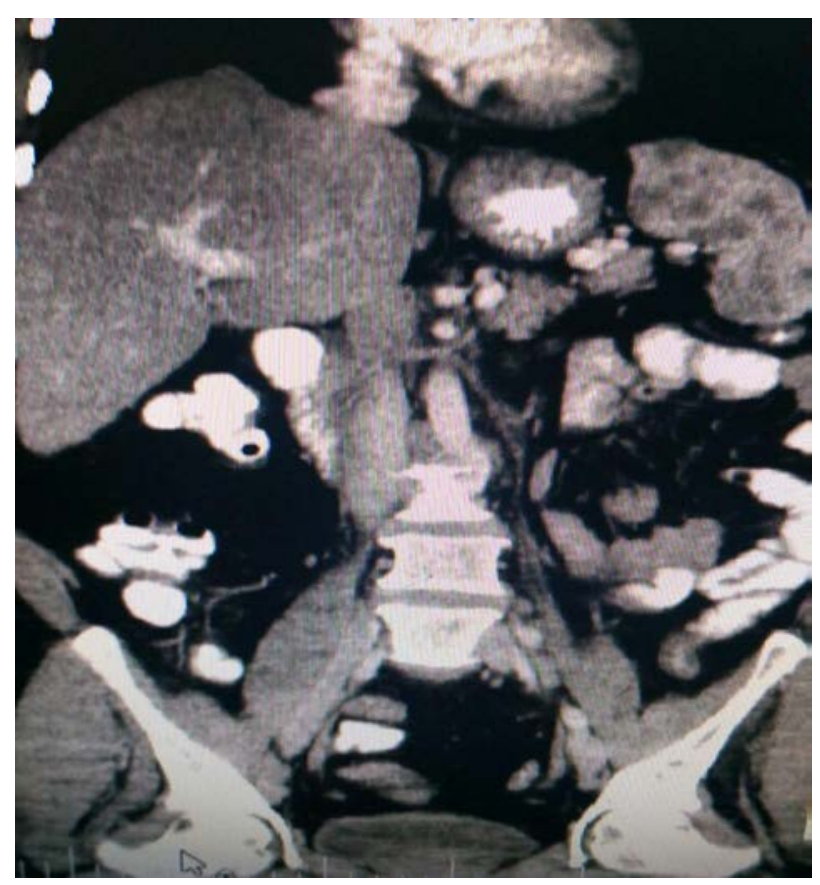

Figure 3. Coronal CT scan disclosed splenomegaly, with multiple hypodense nodules in the spleen and an accessory spleen

ple hypodense nodules in the spleen, and an accessory spleen (Figure 2, 3). Echocardiography found no vegetation. Colonoscopy was performed because of her rectorrhagia that showed decreased vascularity.

After consulting a pulmonologist, an almost definite diagnosis of sarcoidosis was made based on her complaints and imaging findings. Despite the oncologist's recommendation to perform biopsy of the lymph nodes to rule out lymphomas as the most probable differential diagnosis, according to the pulmonologist opinion, her diagnosis was definite, and our patient was diagnosed with Löfgren's syndrome based on her symptoms. Therefore, we treated the patient with prednisone $50 \mathrm{mg}$ daily with a slow tapering rate, without the need for biopsy. Her symptoms and radiographic abnormalities resolved progressively and responded well to treatment.

\section{DISCUSSION}

Sarcoidosis is a chronic granulomatous and inflammatory disease and Löfgren's syndrome is an acute form of sarcoidosis (8). What should be taken into account in diagnosing this disorder is that its differential diagnosis with other diseases such as lymphomas, carcinoma, and tuberculosis should be evidence-based. Two of the following three criteria are needed to diagnose the Löfgren's syndrome: EN, BHL, andarthralgia (7). Our patient had all of these three criteria. Symmetric arthritis in sarcoidosis is very common and ankles are frequently involved joints in this disease; therefore, it is reported in over $80 \%$ of patients (9). Along with the wrists, knees and elbows are engaged but are less visible. Our patient presented with bilateral ankle arthritis.

Ophthalmic involvement in sarcoidosis includes posterior, intermediate, and anterior uveitis (iritis), conjunctival involvement, iris granuloma, posterior synechiae, pupillary abnormalities, episcleritis, scleritis, cataract, vitreous, retinitis, macular edema, and many other manifestations (10). Scleritis was also diagnosed in this case.

The pulmonary involvement is the most usual presentation in Löfgren's syndrome, so that cough, pain, and heaviness in the chest and breathing difficulty are common (11). Our patient had radiographic signs of lung involvements, but these symptoms were absent.

Spleen involvement is not uncommon during sarcoidosis as approximately $5 \%$ of cases with sarcoidosis have splenomegaly on the physical examination and about $30 \%$ on imaging (12). Hypodense splenic nodules are seen on CT in about $10 \%$ of cases (13). This is similar to what happened to our patient. Moreover, splenic granulomas are found at autopsy in about half of the patients with sarcoidosis and hypersplenism due to sarcoidosis, which can lead to pancytopenia (14). A chest $\mathrm{x}$-ray showed bilateral hilar mass lesions and chest HRCT revealed bilateral hilar and paraesophageal lymphadenopathy. It should be noted that tissue biopsy of the most accessible lesion is needed for an exact diagnosis in the absence of Löfgren's syndrome. Therefore, to further investigate these pulmonary masses, biopsies of hilar lymph nodes were recommended by our oncologist, but due to the typical manifestation of Löfgren's syndrome as the classic criteria, we concluded that biopsy was unnecessary and eventually the treatment began.

Erythema nodosum, as a kind of panniculitis, is observed in $90 \%$ of Löfgren's syndrome patients. Sarcoidosis-associated erythema nodosum is usually self-limited and responds to steroids, which indicates good and proper prognosis (15). In our case, a sarcoidosis-related symptom rapidly resolved after the steroid treatment, which was compatible with the characteristics of erythema nodosum in Löfgren's 
syndrome. Laboratory data can help to confirm the diagnosis. Meanwhile, it is important to note that an elevated serum ACE level is not a reliable indicator of disease activity and excludes Löfgren's syndrome, but it can be used as a marker for follow-up of treatment responses and monitoring disease activity (16).

\section{CONCLUSION}

As described, Löfgren's syndrome comprises a triad of BHL, erythema nodosum, and arthritis. Having two of these criteria confirms the diagnosis of the disease, along with investigating the presence of unusual engagement of Löfgren's syndrome, such as spleen involvement which should be taken into consideration by clinicians. Also, exclusion of diseases such as lymphomas should also be considered in the exact diagnosis

\section{Acknowledgements}

The authors thank the Department of Infectious diseases of Babol University of Medical sciences, Iran.

\section{Conflict of interests}

All of authors report no conflict of interest. 


\section{References}

1. Ebrahimpour S, Afshar Z, Sadeghi-HaddadZavareh $M$, et al. Unusual isolated extrapulmonary sarcoidosis: Case report. J Acute Dis 2019;8:38-40.

https://doi.org/10.4103/2221-6189.250377

2. Bargagli E, Prasse A. Sarcoidosis: A review for the internist. Intern Emerg Med 2018;13:325-31. https://doi.org/10.1007/s11739-017-1778-6

3. Baughman RP, Culver DA, Judson MA. A concise review of pulmonary sarcoidosis. Am J Respir Crit Care Med 2011;183:573-81. https://doi.org/10.1164/rccm.201006-0865CI

4. Kobak S, Yalçin M, Sever F, Oncel G. Sarcoidosis Presenting as Löfgren's Syndrome with Myopathy. Case Rep Rheumatol 2013;2013:125251

https://doi.org/10.1155/2013/125251

5. Birnbaum AD, Rifkin LM. Sarcoidosis: SexDependent Variations in Presentation and Management. J Ophthalmol 2014;2014:7. https://doi.org/10.1155/2014/236905

6. Byun CW, Yang SN, Yoon JS, Kim SH. Lofgren's Syndrome-Acute Onset Sarcoidosis and Polyarthralgia: A Case Report. Ann Rehabil Med 2013;37:295-9.

https://doi.org/10.5535/arm.2013.37.2.295

7. Saltman AP, Kuriya B. Löfgren syndrome in acute sarcoidosis. Can Med Assoc J 2017;189:E1230-E.

https://doi.org/10.1503/cmaj.170547

8. Alar T, Gunes F, Muratl EA, et al. Lofgren's syndrome: an acute variant of sarcoidosis diagnosed by mediastinoscopy. J Coll Physicians Surg Pak 2015;25:146-8.
9. Zisman DA, Shorr AF, Lynch JP, 3rd. Sarcoidosis involving the musculoskeletal system. Semin Respir Crit Care Med 2002;23:555-70. https://doi.org/10.1055/s-2002-36520

10. Pasadhika S, Rosenbaum JT. Ocular Sarcoidosis. Clin chest med 2015;36:669-83. https://doi.org/10.1016/j.ccm.2015.08.009

11. Rados J, Lipozencic J, Celic D, Loncaric D. Lofgren's syndrome presenting with erythema nodosum-like eruption. Acta Dermatovenerol Croat 2007;15:249-53.

12. Raber EL, Haba J, Beck P. Splenic sarcoidosis: a case report and review of the imaging findings of multiple incidental splenic lesions as the initial presentation of sarcoidosis. Can J gastroenterol 2011;25:477-8.

https://doi.org/10.1155/2011/748920

13. Gezer NS, Başara I, Altay C, et al. Abdominal sarcoidosis: cross-sectional imaging findings. Diagn Interv Radiol 2015;21:111-7. https://doi.org/10.5152/dir.2014.14210

14. Giovinale M, Fonnesu C, Soriano A, et al. Atypical sarcoidosis: case reports and review of the literature. Eur Rev Med Pharmacol Sci 2009;13 Suppl 1:37-44.

15. Ohta H, Tazawa R, Nakamura A, et al. Acuteonset Sarcoidosis with Erythema Nodosum and Polyarthralgia (L\&ouml;fgren's Syndrome) in Japan: a Case Report and a Review of the Literature. Intern Med 2006;45:659-62.

https://doi.org/10.2169/internalmedicine.45.1452

16. Lin C-M, Li C-H, Horng C-T, et al. A case report of Löfgren's syndrome (a variant of sarcoidosis) with atypical manifestations in a Taiwan Chinese man. Taiwan J Ophthalmol 2012;2:106-8. https://doi.org/10.1016/j.tjo.2012.03.001 


\title{
Lofgrenov sindrom i zahvaćenost slezine: prikaz slučaja
}

\author{
Soheil Ebrahimpour ${ }^{1}$, Mahmoud Sadeghi-Haddad-Zavareh ${ }^{1}$, Zeinab Mohseni Afshar ${ }^{2}$, \\ Mehran Shokri ${ }^{1}$, Arefeh Babazadeh ${ }^{1}$ \\ ${ }^{1}$ Istraživački centar za infektione i tropske bolesti bolseti, Zdravstveni istraživački institut, \\ Univerzitet medicinskih nauka u Babolu, Babol, Iran \\ ${ }^{2}$ Klinički istraživačko-razvojni centar, Bolnica Imam Reza, Univerzitet medicinskih nauka \\ u Kermanshahu, Kermanshah, Iran
}

\section{SAŽETAK}

Lofgrenov sindrom je akutna forma sarkoidoze i karakteriše se pojavom povišene telesne temperature, eriteme nodozum, bilateralne hilarne limfadenopatije i poliartritisa. Ovaj sindrom je bolest koja spontano prolazi. U našu bolnicu, primljena je četrdesetpetogodišnja žena koja se žalila na povišenu telesnu temperaturu, zamućen vid i bolove u zglobovima. Snimak pluća bilateralno je pokazao mase u okolini hilusa. Kompjuterizovana tomografija visoke rezolucije grudnog koša ukazala je na brojne čvoriće u različitim segmentima pluća, kao i na bilateralnu hilarnu i paraezofagijalnu limfadenopatiju. Kompjuterizovana tomografija takođe je pokazala blagu splenomegaliju, sa brojnim čvorićima manje gustine $u$ slezini, kao i akcesornu slezinu. Bolesnici je postavljena dijagnoza Lofgrenovog sindroma.

Ključne reči: Lofgrenov sindrom, sarkoidoza, poliartritis, eritema nodozum 